\title{
Social Entrepreneurship As Seen By the Future Managers
}

\author{
${ }^{1}$ Anna Pereverzieva, ${ }^{2}$ Volodymyr Volkov \\ ${ }^{1}$ Associate professor of International economy, natural resources and economic theory department, \\ Zaporizhzhya national university, Ukraine, Zaporizhzhya \\ ${ }^{2}$ Professor of Entrepreneurship, Management of Organizations and Logistics department, Zaporizhzhya \\ national university, Zaporizhzhya national university, Ukraine, Zaporizhzhya
}

\begin{abstract}
Present society development faces a significant growth in unemployment in all countries around the world, regardless of the level of their development, and a decrease in income. Instability in the economy causes inability to meet population basic needs at the expense of available opportunities. There is a need to expand social entrepreneurship, launching of social enterprises, whose activities are based on innovative business models with a predominant focus on solving social problems. The entities` management requires training of management professionals able to deal with complex economic and social issues, rather than performing certain functions. The authors argue that it is the propensity / aversion to social entrepreneurship that determines the prospects for its development in a particular country. To test the hypothesis, a questionnaire was developed and a survey of students of different courses in economics and management was conducted. The questionnaire contained questions that allow us to consider the understanding of social entrepreneurship essence, the role of gender in social business, highlight key characteristics of social entrepreneurship and identify prospects for this innovative model through the propensity / aversion to social entrepreneurship.

The study objective is to determine the propensity / aversion to social entrepreneurship in order to outline the future prospects for the formation of a new business model with value orientations on human resources. The results of the study demonstrated the importance of social entrepreneurship amid economic uncertainty and external threats. The vast majority of respondents have propensity and are ready to do business based on the innovative model of socially-oriented business. However, there is a fundamental belief in the psyche of people in economic benefits, but not the combination of social mission with efficiency, which is the basis of social business.

The study could be a starting point for identifying areas to improve managers training through identification of key social orientations, which will help in the future to intensify the development of innovative business models aimed at solving socio-economic problems of a society.
\end{abstract}

Keywords: Social entrepreneurship, Social entrepreneur, Business-model, Social value.

\section{Introduction}

All the economies are significantly affected by present day's global challenges, which have both negative and positive consequences for socio-economic development, regardless of the country's ranking in the international arena. It should be noted that the higher the level of countries` development is, the greater are the opportunities to choose the development trajectory and move with the least social losses. The resource potential and countries` development capacity are insufficient to overcome the negative facets of the threats to mankind.

Economic instability impact, such as rising unemployment, uneven income distribution, declining solvency and inability to meet basic needs becomes driving force for rethinking existing managerial mechanisms and finding a new way of doing business that will balance social and economic goals.

Higher interdependence between countries in the context of globalization raises the issue of consolidated solution to common problems. After all, the successes and failures of one country are projected on a global level and weaken the world economy as a whole. 
Traditional managerial methods have proved their inefficiency in meeting population needs, reaching personal and public interests. Under the conditions, social entrepreneurship becomes one of the sources of achieving stability in a society. Of course, the business model of social entrepreneurship does not solve all the existing problems, but creates opportunities to reduce their negative impact by efficient combination of innovative business model with market tools. Social enterprises duality is revealed not only in commercial and non-commercial purposes, but also in a balance between social (solving socio-economic problems) and personal development of an entrepreneur (enrichment, energy, self-realization, self-improvement, social consciousness).

Social entrepreneurship is a new phenomenon in most economies. It requires in-depth theoretical and practical study, training of professionals able to combine efficient business models with social values. To determine the prospects for the future, it is important to assess potential for social entrepreneurship in society. The above is implemented by us in the study through the achievement of the objective: determining the propensity / aversion to social entrepreneurship to outline the future prospects for the formation of a new business model based on value orientations on human resources.

We propose the following hypotheses for testing: (H1) social entrepreneurship specifies future prospects of its development; (H2) majority of people have propensity to social entrepreneurship.

The article has a clear structure; the elements are logically presented. Literature review provides the analysis of certain aspects of social entrepreneurship: the concept "Social entrepreneurship", social entrepreneur, gender aspects of social enterprises`activities and international experience of social entrepreneurship. Survey detailed analysis have been provided. The article concludes with the discussion issues, results and prospects for the future research.

\section{Literature review}

There are trends of social entrepreneurship studies in the scientific literature, namely the concept of social entrepreneurship, role of a social entrepreneur, gender aspects of social enterprises' activities and international experience of social entrepreneurship (figure 1).

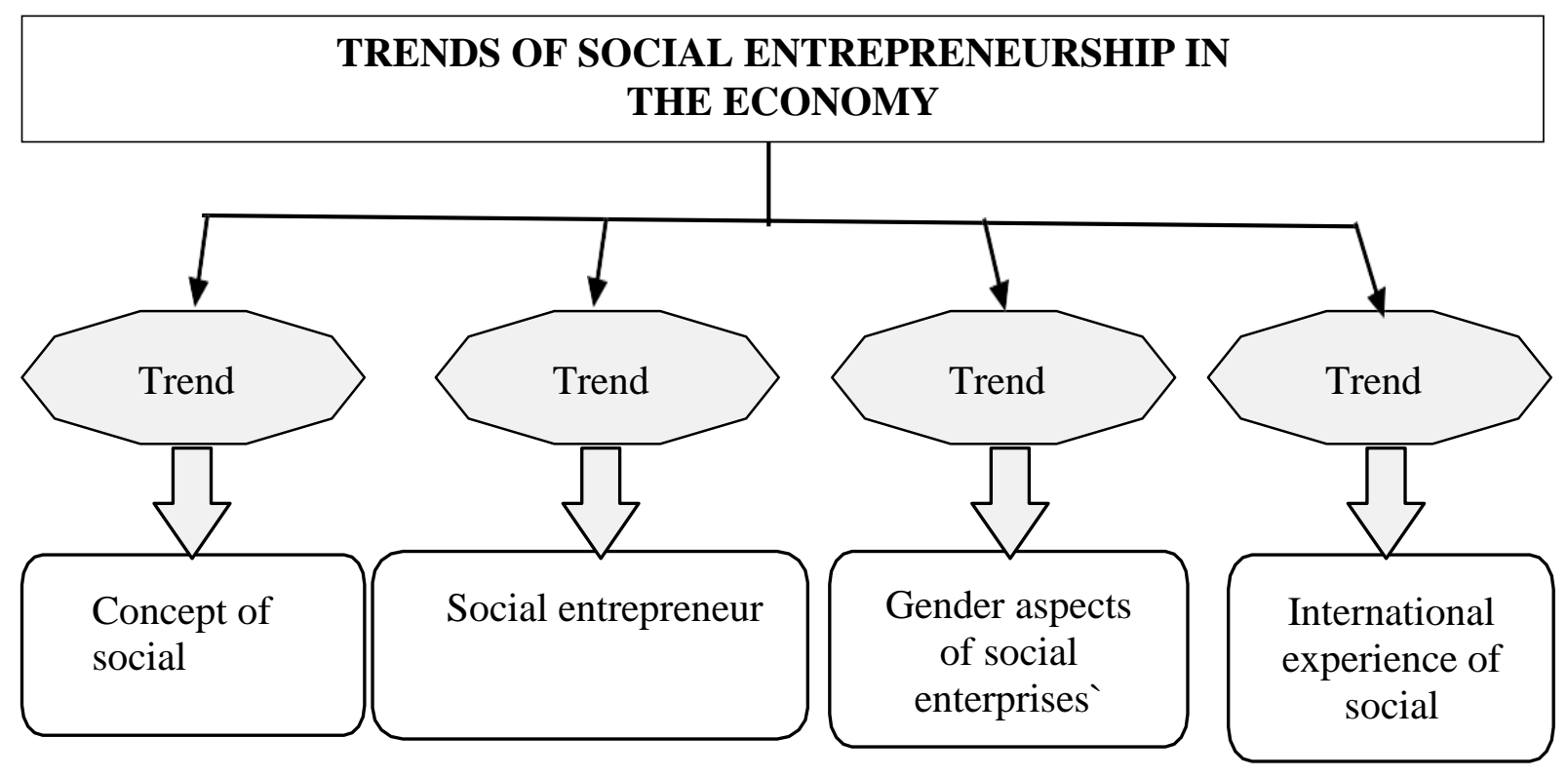

Figure 1: Research trends of Social entrepreneurship in scientific literature

\section{Source: own study}

\section{Concept of "Social entrepreneurship"}

The issue of a unified approach to the theoretical definition of "social entrepreneurship" concept is unresolved, although there are some scientific views on the interpretation of this economic category. It should be noted that first it is necessary to legislate the definition of social entrepreneurship in order to regulate the entities`activities, as well as to identify the framework of its economic and social environment. 
In most countries, this issue remains open, nevertheless social business activities are regulated within the existing legal framework that is like the registration of a similar organizational and legal business form.

Most scholars define the concept of "social entrepreneurship" as the criterion for the dominance of noncommercial goals over commercial ones, which are a way to address social issues (Zulkefly, Ghani \& Alquliti, 2019). In our opinion, within social entrepreneurship, the dominance should be combined with noncommercial and commercial goals`complementarity and considered as a holistic system.

Doherty, Haugh \& Lyon (2014) studied social enterprises as a hybrid form of business organization able to overcome 2008 crisis, rising unemployment and low living standards. Scholars define social enterprises as organizations that combine entrepreneurship with an embedded social goal, indicating the hybridity of its goals, namely pursuit of financial sustainability and social purpose (Battilana \& Dorado, 2010, Besley \& Ghatak, 2017). Bull \& Ridley-Duff (2019) focus on opposite issues on hybridity. Scholars deviate from the traditional concept of "hybrid blend of mission and market (purpose-versus-resource)" and consider social entrepreneurship as a combination of economic system (redistribution, reciprocity and market) and social value orientation (personal, mutual or public benefit).

Researches pay considerable attention to the impact of hybridity on the features of governance system, human and financial resources attraction (Ebrahim, Battilana \& Mair, 2014). Scholars examine managerial challenges of organizations that pursue a social mission through the use of market tools. They distinguish two ideal types of the hybrids - differentiated and integrated, and two key challenges of governance they face: accountability for social and economic performance objectives and accountability to principal stakeholders. The paper theoretically proves the importance of organizational governance and the role of governing boards in prioritizing and reconciling potentially conflicting objectives and interests to avoid mission drift and to support organizational hybridity in social enterprises.

Newman, Neesham, Manville, Tse \& Herman (2018) considered the impact of different leadership styles on the organizational commitment and innovative behaviour of employees working in social enterprises. Researchers have proved that leadership positively affect innovative behaviour of employees, in contrast to coercive leadership methods.

Bridgstock, Lettice, Ozbilgin \& Tatli (2010) analyzed correlation between management system, innovation and performance of social enterprises. Scholars have shown that social enterprises exhibit unique and innovative characteristics, adding economic and social value to the solution of society's issues. However, some scientific results show that social value orientation of a company weakens its economic performance, which could potentially be higher, if a different business model had been chosen (Battilana, Sengul, Pache \& Model, 2015). The reasons for poor growth of "social entrepreneurship" innovative ventures are the inefficient knowledge management process, rather than lack of resources (Maalaoui, Le Loarne-Lemaire \& Razgallah, 2020), which was proved by the scholars who linked knowledge management theory and advances within social entrepreneurship study.

Comparative analysis of social entrepreneurship with traditional business models is presented in the study of Dacin, P.A., Dacin, M.T., Matear, 2010, Dacin, M.T., Dacin, P.A. Tracey, 2011). Choi \& Kim (2020) analyzed the attitudes of employees of commercial and social enterprises to profit and social mission. The research is a significant contribution to the definition of psychological mechanisms, which are the basis of individual's perception and attitude to social enterprises.

Drayton (2019) defined "social entrepreneurship" focusing on two key characteristics - innovation and the ability to address social issues, which are especially relevant for less developed and developing countries as a tool to accelerate their socio-economic development.

Some scholars (Kickul \& Lyons, 2016) consider social entrepreneurship as an opportunity to change the world, which is relevant in the context of global issues intensification, the need to consolidate the efforts of all countries and rethink the priorities of future development.

Conceptual perspectives to formulate a new social entrepreneurship system have identified five key aspects of social entrepreneurship, namely social welfare, social capital, social entrepreneur, economic value creation, and collective endurance (Sengupta, Sahay \& Croce, 2018). 
Moizer \& Tracey (2010) study the issues of social enterprise strategy building. As the business model has both social and commercial goals, social enterprises face a high level of complexity in developing their strategies. They should not only get sufficient income to reinvest in their economic activities, but should also support investment in their community's social projects. Resource scarcity is a major setback to business long-term stability.

Thus, the issue of the theoretical definition of "social entrepreneurship" is debatable and promising in terms of future research (Acs, Boardman \& McNeely, 2013, Battilana \& Lee, 2014, Choi \& Majumdar, 2014, Gandhi \& Raina, 2018, Gupta, Chauhan, Paul \& Jaiswal, 2020).

Analysis of the peculiarities of social enterprises activities provided by scientists (Agustina, Budiasih, Ariawan \& Gorovoy, 2020) reveal that government support is one of the priority determinants for the effective operation of this innovative business form, which primarily involves regulation and creation of favourable social and economic conditions.

The importance of government support clearly emphasizes the need to formulate criteria for distinguishing social business (Schambra, 2010). It is noted that public policy should promote the introduction of social innovation at the regional and national economic levels (Keohane \& Levenson, 2013).

In their studies, scholars (Sahasranamam \& Nandakumar, 2018) highlight the characteristic features of state institutions` impact and role on social enterprises` functioning and development.

Nandan, Bent-Goodley \& Mandayam (2019) fulfilled thorough analysis of social entrepreneurship and peculiarities of social values portfolio formation. Scholars study present social entrepreneurship trends of development, determine the features of the business form organization based on innovative strategies for solving complex social issues.

One of the essential activities of a social enterprise is assessment of social value and economic efficiency. Krocil \& Pospisil (2015) have proposed a set of instruments that can be used by social entrepreneurs or government agencies to effectively and comprehensively measure social value and contribution to the overall performance. Bagnoli \& Megali (2011) substantiated the importance of social impact assessment to determine the completeness of the strategic mission. Researchers have proposed models that help social entrepreneurs choose the business model that best meets the needs of their organization.

Dahiya (2019) considers social entrepreneurship as an alternative to solving social issues due to the efficiency of business models and the market in case fails to fully meet all the population needs. This is achieved, according to Battilana \& Lee (2014) through the combination of organizational forms and charity, which makes a social enterprise an ideal type of a hybrid organization.

Dacin T., Dacin M. \& Tracey (2011) studied contradictory aspects of social enterprises performance, analyzing advantages and disadvantages of this business form, and determining future development prospects.

Kochlami, Davidsson, Obschonka, Yazdanfar \& Lundstrom (2020) proved positive employment effects of social entrepreneurship. The economic role of a new firm formation, of a social enterprise, is to create new jobs and increase employment rate. In addition, social entrepreneurship induces significant positive changes in social, economic and political contexts for poor (Maseno \& Wanyoike, 2020). Researchers have formulated propositions about fundamental innovations, leadership and operation, and scaling up in social enterprises that produces sustainable impact.

Chandra Y. (2017) devoted his work to the psychological impact of social entrepreneurship. The scientist argued that self-confidence is constructed by the engagement in social entrepreneurship. It allows not only to avoid some ideological constraints, but also build a new meaning of life, new social roles and connections that provide platform for shaping new future. This is important, because social entrepreneurship is a form of organization providing autonomy with a simultaneous focus on profitability, achieving a high degree of emancipation for both entrepreneurs and those they serve. 
Thus, according to Farinha, Sebastião, Sampaio \& Lopes (2020) nowadays-social entrepreneurship is of paramount importance in the service and public sectors, as it significantly affects the solution of poverty issues and social needs safety.

Roslan, Hamid, Ijab \& Bukhari (2019) consider that it is necessary to create special centers that provide support to social enterprises by organizing seminars, trainings and more.

\section{A social entrepreneur}

Importantly, an individual - a social entrepreneur - plays a special role in the activities of any business entity, regardless of the dominance of its commercial or non-commercial purposes. Most scholars as Sahasranamam \& Nandakumar (2018) are inclined to believe that the mission of social entrepreneurs requires the formation of a special environment and direct correlation between the development of individual capital of a social entrepreneur and government institutions.

Personal qualities of a social entrepreneur, his role in the organization and successful functioning of the innovative business model may be considered a promising aspect of study. Scholars pay special attention to entrepreneurial skills and psychological capital (Guo, Liu \& Yain, 2020). Cohen, Kaspi-Baruch \& Katz (2019) proved that social entrepreneurs have stronger early ideological and leadership training. Regression analysis found out that a relatively robust and persistent set of internal psychological motives encourages the search for specific experiences related to leadership roles and social change orientations, including social entrepreneurship and relevant practical experience in adolescence and young adulthood.

Jeong, Bailey, Lee \& McLean (2020) identified three time-sequential themes: past (origin, family), present (real life of a social entrepreneur) and future (vision of prospects) to define and systematize individual characteristics of a social entrepreneur. This allowed to reveal such important individual traits as leadership, sustainability orientation and social entrepreneurs' aspiration.

Fernandez-Laviada, Lopez-Gutierrez \& San-Martin (2020) proved the impact of the country`s level of development on the factors that determine social entrepreneurs` behaviour. The results show that factors that determine the values and skills to start a business are those related to the environment, distinguish a social entrepreneur from a traditional entrepreneur. The development of the country plays a crucial motivating role, modifying the effect of the values and skills to be a social entrepreneur. It depends on gender and is relevant of entrepreneurs' perception of their environment.

Researchers point out that social entrepreneurs are agents of change who challenge the hypothetical assumption of the incompatibility of a social good and entrepreneurship. This view is confirmed by the study of Byungchae Jin (2019), who proved the correlation between the practical intelligence of social entrepreneurs and the effectiveness of business management, which combines both economic and social goals.

However, Grimes, Vogus, McMullen \& Miller (2013) emphasize that in today's economy, a social entrepreneur is typically an "embedded agent", whilst it must be a deeply motivated person willing to take on such a role.

\section{Gender aspects of social enterprises`activities}

From a gender perspective, researchers argue that social entrepreneurship is primarily a tool of selfrealization for women who are agents of change in the modern economy (Rosca, Agarwal \& Brem, 2020). It is considered as a stereotype that women are busy with household routine. The study conducted by the scholars proves that social entrepreneurship creates opportunities for women willing to make a career as an entrepreneur. It is also important to provide an appropriate environment for the development of social entrepreneurship and increase women's participation in social business: financial capital - provision of financial assistance through funds of international institutions, grant programs; human capital - formal and informal learning; social capital - creation of a network for women`s social entrepreneurship. We can agree with this point of view, because women social entrepreneurs are more motivated to address social issues, taking into account individual characteristics of their psycho-physical conditions. Male entrepreneurs are focused on getting results in the form of profit. 
One of the ways to boost women`s social entrepreneurship is to create associations that offer selfemployment opportunities, promote high motivation concerning social issues and women business opportunities (Datta \& Gailey, 2012). Researchers have analyzed two main areas of development for female social entrepreneurs: elements of business models that promote women's empowerment and individual perception. At the same time, a special role is given to family social entrepreneurship. The advantage of social entrepreneurship`s collective family leadership is a higher level of economic security, formation of entrepreneurial skills and increased contribution to the common cause. It should be noted that the business model is quite unstable, and in case of conflict, it can lead to the economic collapse of business, which due to its social orientation will negatively affect those who need the enterprise.

Ferdousi \& Mahmud (2019) studied the impact of social business on women`s entrepreneurship growth in Muslim countries.

\section{International experience of social enterprises and social entrepreneurship}

Internationally, social enterprises' transfer is uneven and there are noticeable differences that reflect national characteristics of welfare, labour market and ideology (Kerlin, 2010; Chell, Nicolopoulou \& Karatas-Ozkan, 2020, Melkas, 2020). Social enterprises are designed to seek business solutions to social problems promoting innovations. The study defines innovative solutions of a social enterprise to solve issues of social integration, social behaviour and socio-economic development. Canestrino, Cwiklicki, Magliocca \& Pawelek (2020) note that cultural values, regional affiliation and level of economic development affect social entrepreneurship peculiarities in different countries.

The study of social entrepreneurship in the EU is quite common in the professional literature (Kolakovic, Turuk, \& Turcic, 2018, Liptrap, 2020, Hojnik \& Crnogaj, 2020). Researchers analyze the specifics of social entrepreneurship in different business environment, some characteristics of social enterprises, namely social value, innovation and market activity. It is substantiated that social enterprises should operate in a specific business context, which significantly hinders or promotes social entrepreneurship. As northwestern and southeastern Europe has different cultures, scholars emphasize the importance of social entrepreneurship contrast studying for two groups of countries. The results show that social entrepreneurship is more developed in the countries of north-western Europe than in the south-east. Lambooy, Anthoni \& Argyrou (2020) considered certain aspects of social entrepreneurship legal regulation in the EU. Social enterprises demonstrate sustainability that can be built into business. It involves choosing the legal form and business model aimed at achieving social and public goals. The European Union (EU) member states have developed the legal standards of social enterprises activity, which demand providing a "public goal", "public mission" and "public benefit" by a social enterprise.

The necessity to expand and internationalize social enterprises was considered (Angulo-Ruiz, Pergelova \& Dana, 2020; Bretos, Diaz-Foncea \& Marcuello, 2020). Their study results have proved that social hybrid firms could internationalize faster, if the economic relations are properly organized. However, social networking and government support reduce the internationalization of social hybrid firms.

Corner \& Kearins (2018) proved the need of social entrepreneurship dissemination. They demonstrated direct correlation between the number of social enterprises and the number of social problems solved.

Based on our own research using econometric tools, we proposed the assessment method of the need for social entrepreneurship and the environment, created in a particular country for its development (Pereverzieva \& Volkov, 2019).

Critical analysis of scientific works devoted to the theoretical study of "social entrepreneurship" concept, various aspects of its development and the selection of the key determinants, as well as the impact of individual determinants on the effectiveness of business models and their mission confirms the need for the innovative business form in the majority of countries, regardless of the level of their economic development. Each of the national economies is affected by global problems, the solution of which is not provided by traditional forms of management. This requires thorough theoretical and practical training of a new generation of professionals, able to make their own decisions and be responsible for the consequences, and not just act as reliable performers of certain functions. There is a global task to train effective managers 
based on European values with a developed social consciousness and the ability to build an effective business model aimed at global development.

\section{Methodology/Research methods}

In order to determine the prospects for social entrepreneurship as innovative business form`s development, we conducted a survey (in the form of questionnaires) among Faculty of Economics' and Faculty of Management`s students of Zaporizhzhia National University. Their propensity / reluctance to promote social entrepreneurship was identified. This target group was chosen, because it belongs to the specialties "Economics" and "Management and Administration", which provide training for managers (building of innovative business models) and economists (efficient management). The future experts must create, effectively manage and develop social entrepreneurship having individual social qualities. The survey results allowed to obtain general understanding of social entrepreneurship, personal traits of a social entrepreneur and to take into account the gender aspect.

The study involves testing the following hypotheses:

(H1) propensity / aversion to social entrepreneurship determines the future prospects of its development;

(H2) majority of people have propensity to social entrepreneurship.

General characteristics of the survey are presented in table 1.

\section{Table 1: Survey general characteristics}

\begin{tabular}{|c|c|c|c|c|c|c|}
\hline Characteristics & \multicolumn{2}{|c|}{ Number of surveyed } & Female & & \multicolumn{2}{|c|}{ Male } \\
\hline & persons & $\%$ & persons & $\%$ & persons & $\%$ \\
\hline Managers & 63 & 37,7 & 109 & 65,3 & 58 & 34,7 \\
\cline { 1 - 3 } Economists & 104 & 62,3 & & & & \\
\hline Total & 167 & 100 & 109 & 65,3 & 58 & 34,7 \\
\hline
\end{tabular}

\section{Source: own study}

167 people took part in the survey, including 63 managers, which is $37.7 \%$ of the total number of the respondents and 104 economists $-62.3 \%$. Most of the respondents are female -109 people $(65.3 \%)$, which allowed us to analyze the gender aspect of social entrepreneurship.

\section{Analysis and discussion of the results}

The research methodology involves testing two hypotheses: (H1) a social enterprise determines the future prospects of its development; (H2) majority of people have propensity to social entrepreneurship. The first hypothesis was proved by us on the basis of the analysis of scientific researches concerning social entrepreneurship. Social entrepreneurship incorporates effective business models with social values in a single management system, which becomes its distinctive feature. Social effect dominance along with economic effect presence are the result of business entity performance. Besides, a social enterprise does not only solve important macroeconomic socio-economic problems, but also induces individual's - a social entrepreneur`s - self-realization at microeconomic level. Peculiarities of legal, economic and social environment of any country significantly affect social enterprises`activities and development. Individual initiative, public perception and government support are considered as extremely important determinants for the innovative business form`s success.

The second study hypothesis was tested by surveying future specialists in the field of economics and management. The results showed that $90.9 \%$ of the respondents would like to start their own business in the future, which confirms the significant potential for private initiative. However, the issue of social entrepreneurship future remains open. According to $50.3 \%$ of respondents, commercial goals (profit) are the key ones for social entrepreneurship, which contradicts the theoretical definition of the category. That is, there is a desire to run business, to take responsibility for the decisions made, but still the key priority is the economic effect, not social goals. 
The aptitude for management is confirmed by the fact that $84.2 \%$ of respondents want to be managers, but not "good employees", i.e. to perform duties conscientiously. Moreover, managerial skills are formed by the experience, as it was noted by $86.7 \%$ of the total number of respondents.

On the positive side, the main purpose of social entrepreneurship, according to respondents, is solving social problems $(70.9 \%)$ and self-realization $(24.2 \%)$.

Of course, the effective development of social entrepreneurship requires the appropriate environment. We analyzed biggest challenges facing the field of social entrepreneurship (figure 2).

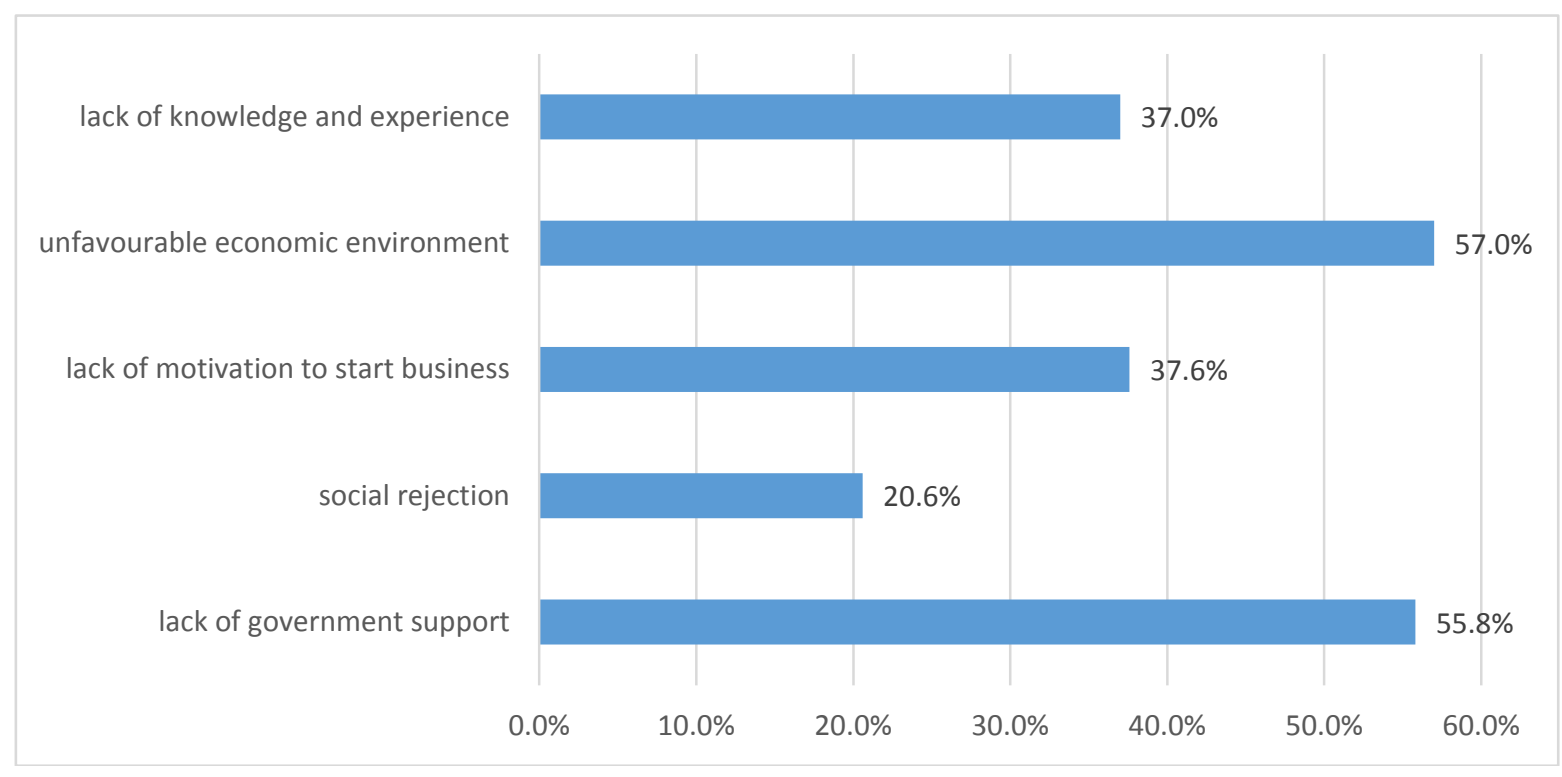

\section{Figure 2: Biggest challenges facing the field of social entrepreneurship}

Note: two options must be chosen

\section{Source: own study}

According to the respondents, the biggest obstacle to the development of a social enterprise is unfavourable economic environment $-57.0 \%$, the second is lack of government support $-55.8 \%$. The survey results proved that social rejection is the least threat to social entrepreneurship $-20.6 \%$.

Personal characteristics of a social entrepreneur play a significant role in the activities of a social enterprise. The key characteristic of a social entrepreneur according to the survey results is the level of his/hers responsibility for the outcomes to society $-27.9 \%$ (figure 3 ).

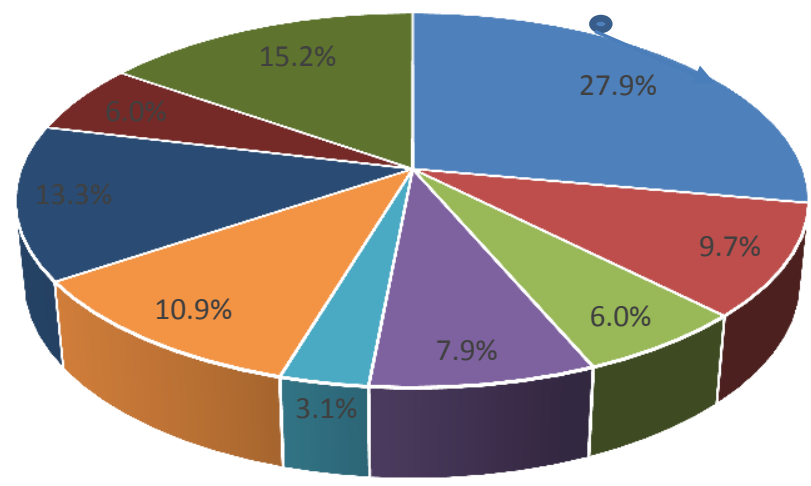

$$
\begin{aligned}
& \text { level of responsibility for outcomes to } \\
& \text { society and individuals } \\
& \text { - innovation in resource distribution and } \\
& \text { concentration for social targets fulfilment } \\
& \text { - dominance of commercial purposes over } \\
& \text { non-commercial } \\
& \text { - focus on efficiency, competitiveness and } \\
& \text { return } \\
& \text { - motivation to create new jobs }
\end{aligned}
$$


Figure 3. Personal characteristics of a social entrepreneur

Source: own study

Innovation in the resource distribution and concentration is also important (15.2\%). That is, these results correspond to the concept of social entrepreneurship - the symbiosis of innovative business - model and social values.

To determine the level of respondents`awareness of the differences between traditional business forms and social entrepreneurship, the question was formulated by us in the questionnaire "What do you think distinguishes social entrepreneurship from traditional?" (Figure 4). Propensity for solving certain social problems based on the most effective business practices was defined as the main difference from traditional business forms $-61.8 \%$ of the number of respondents.

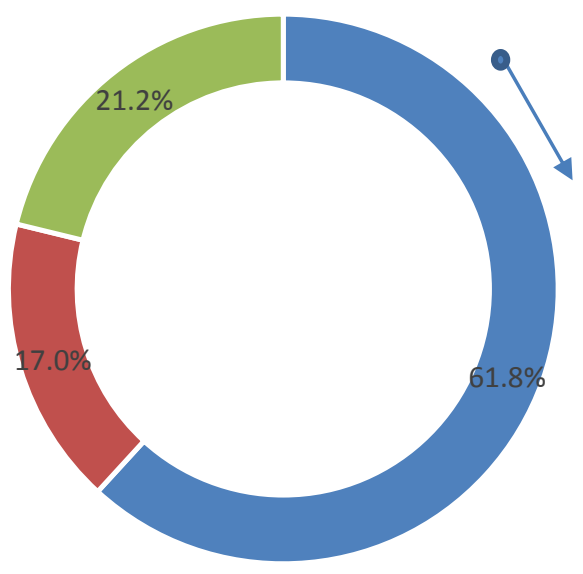

$$
\begin{aligned}
& \text { - Propensity for solving certain social } \\
& \text { problems based on the most effective } \\
& \text { business practices } \\
& \text { - The presence of innovative } \\
& \text { component, i.e. goods or services } \\
& \text { production, which did not exist } \\
& \text { before in the market and create } \\
& \text { added value } \\
& \text { Income distribution as for the share } \\
& \text { of the received net income's } \\
& \text { investment to fulfill social task } \\
& \text { determined at the starting point of } \\
& \text { business }
\end{aligned}
$$

\section{Figure 4: Distinctions of a social and traditional enterprise}

\section{Source: own study}

According to the survey results, $67.3 \%$ of respondents determined that activities for the sake of community or a certain group, which indirectly contribute to the formation of social responsibility at local and global levels, define social entrepreneurship through its main goal (figure 5).
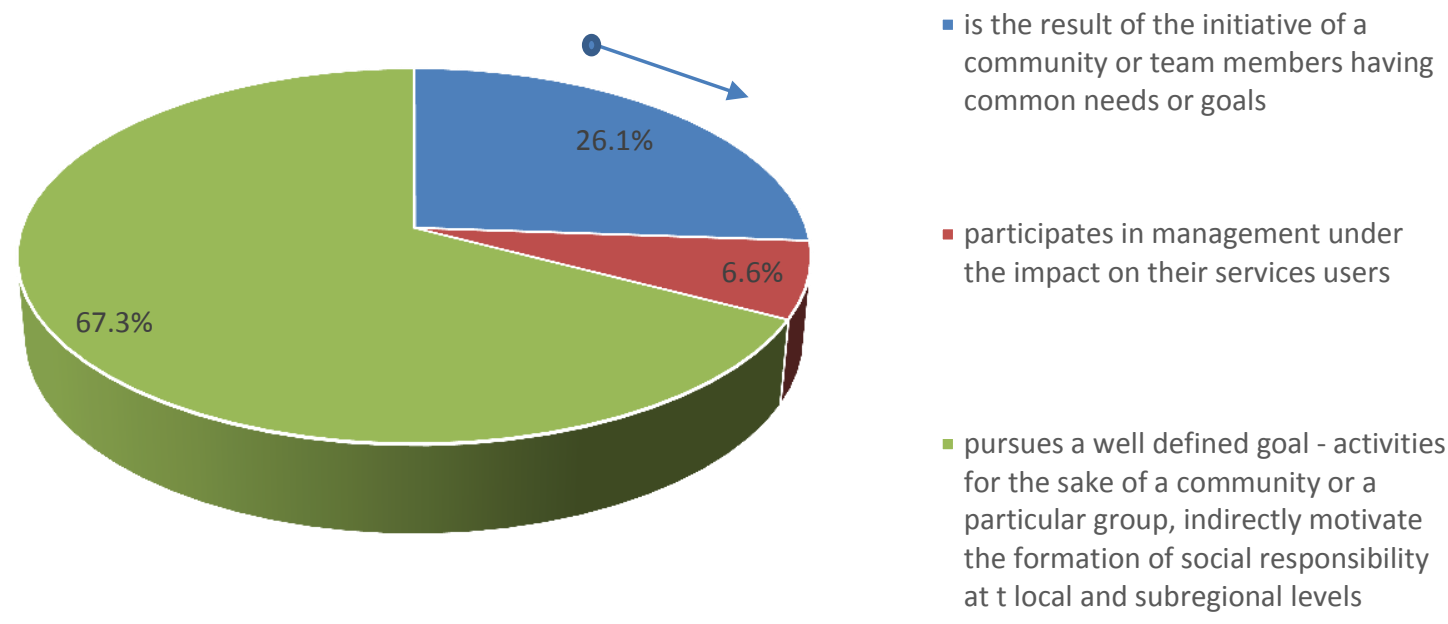

Figure 5: Respondents' understanding of the peculiarities of social entrepreneurship 
Respondents consider that promising areas for social entrepreneurship are socio-cultural services (63.6\%), information and consulting, licensing and financial services (41.2\%), housing and utility services (40.6\%). The least attractive are communication services (17.0\%), manufacturing (20.6\%).

\section{Discussion}

The study objective was to theoretically define the concept of social entrepreneurship and its features based on the analysis of scholars works and practical determination of propensity / aversion to social entrepreneurship to outline future prospects for the formation of a new business model with value orientations on human resources in countries with different levels of economic development. We have made a significant literature review that shows the lack of a unified approach to the interpretation of the concept of "social entrepreneurship", but allows us to formulate and highlight a number of features related to the qualities of a social entrepreneur, gender aspects and different indicators of socio-economic environment in various countries.

In our opinion, the prospect of social entrepreneurship development as of an effective business model focused on social values is the aptitude for this form of business and propensity / aversion to it. To do this, we conducted a survey of economics and management students. The results showed that the vast majority reveal a desire to have their own business and develop private initiative. However, this initiative is mainly aimed at making a profit, rather than realizing social problems, which contradicts the main mission of a social enterprise.

The added value of the study is understanding and perception of the difference between a "manager" and a "good employee". The positive part is the desire of students to be managers, whose training is mainly grounded on practical experience. Social immaturity of the respondents is a challenge for the modern content of education, which requires reshaping of the education system to practice-biased courses. The formation of the necessary competencies of a specialist should be carried out on the basis of both theoretical and practical knowledge in a logical sequence with a clear structure. Economic study programmes should be socially oriented and combine the principles of creativity with the reliance on universal values.

\section{Conclusion}

In our article, we provided a thorough theoretical analysis of the innovative form of business that combines economic efficiency with social orientation. Practical results were obtained based on the survey on propensity / aversion to social entrepreneurship. It showed the prospects of social entrepreneurship development, the desire of the vast majority of respondents to realize their abilities by starting their own business, which is confirmed by the willingness to be managers rather than "good performers".

Taking into account, that the majority of respondents are female, it can be concluded that social entrepreneurship is an instrument of self-realization for women, which may be associated with individual characteristics, character, temperament and socio-psychological orientations.

The biggest challenges facing the field of social entrepreneurship development are the complex imperfections of the economic environment and government support. The least important challenge is social perception. This confirms the hypothesis that the initiative should primarily come from the state through incentives and support based on differentiated fiscal policy.

For convenience, we summarize the results for the hypothesis below:

(H1) propensity / aversion to social entrepreneurship determines the future prospects of country`s development, is adopted;

(H2) majority of people have propensity to social entrepreneurship, is adopted.

Our work is not without limitations. It is necessary to take into account not only the propensity /aversion of specialists to social entrepreneurship, but also legal, current economic environment, the level of "social entrepreneurship" phenomenon perception.

Of course, our task for further research is to identify the key determinants influencing the framework of social entrepreneurship functioning and development from microeconomic to macroeconomic levels, taking into account the peculiarities of the development of each country. The methodology will allow us to identify 
opportunities and threats to social entrepreneurship at different levels of the economy. Microeconomic analysis will make it possible to identify the countries that have the most favourable conditions for starting their own business. Macro level study will identify rational areas for improving the legal and socioeconomic environment to support private initiative in socio-oriented business on the basis of creative management decision-making.

\section{Acknowledgment(s)}

This research is performed in the framework of the state budget project. The state registration number 0119U000224 «Geospatial and infrastructural restructuring of decentralized self-governing socio-economic associations of multi-vector development» (number of state registration »(2019-2021), Zaporizhzhia national university

\section{References (APA Style $6^{\text {th }}$ )}

[1.] Acs, Z.J., Boardman, M.C., McNeely, C.L. (2013): The social value of productive entrepreneurship. Small business economics, 40 (3), 785-796. DOI: 10.1007/s11187-011- 9396-6.

[2.] Agustina T., Budiasih Y., Ariawan K. E., Gorovoy S. A. (2020): Role of social entrepreneurship in business management. Journal of Critical Reviews. No. 7 (1). Pp. 257-262.

[3.] American economic journal-economic policy, 9 (3), 19-58. DOI: 10.1257/pol.20150495.

[4.] Angulo-Ruiz, F., Pergelova, A., Dana, L.P. (2020). The internationalization of social hybrid firms. Journal of business research, 113, 266-278. DOI: 10.1016/j.jbusres.2019.10.017.

[5.] Bagnoli, L., Megali, C. (2011). Measuring Value Creation in Social Enterprises: A Cluster Analysis of Social Impact Assessment Models. Nonprofit and voluntary sector quarterly. 44 (6). 1173-1193. DOI: 10.1177/0899764014555986.

[6.] Battilana, J. \& Dorado, S. (2010). Building sustainable hybrid organizations: the case of commercial microfinance organizations. Academy of management journal, 53 (6), 1419- 1440. DOI: 10.5465/AMJ.2010.57318391.

[7.] Battilana, J. and Lee, M. (2014) Advancing Research on Hybrid Organizing - Insights from the Study of Social Enterprises. The Academy of Management Annals. 8(1). 2014. DOI: 10.1080/19416520.2014.893615.

[8.] Battilana, J., Lee, M. (2014). Advancing Research on Hybrid Organizing - Insights from the Study of Social Enterprises. Academy of management annals, 8 (1), 397-441. DOI: 10.1080/19416520.2014.893615.

[9.] Battilana, J., Sengul, M., Pache, A.C. \& Model, J. (2015). Harnessing productive tensions in hybrid organizations; the case of work social enterprises. Academy of management journal, 58 (6), 16581685. DOI: 10.5465/amj.2013.0903.

[10.] Besley, T., Ghatak, M. (2017). Profit with Purpose? A Theory of Social Enterprise.

[11.] Bretos, I., Diaz-Foncea, M., Marcuello, C. (2020). International Expansion of Social Enterprises as a Catalyst for Scaling up Social Impact across Borders. Sustainability, 12 (8). DOI: 10.3390/su12083262.

[12.] Bridgstock, R., Lettice, F., Ozbilgin, M.F. \& Tatli, A. (2010). Diversity management for innovation in social enterprises in the UK. Entrepreneurship and regional development, 22 (6), 557-574. DOI: 10.1080/08985626.2010.488404.

[13.] Bull, M., Ridley-Duff, R. (2019). Towards an Appreciation of Ethics in Social Enterprise Business Models. Journal of business ethnics, 159 (3), 619-634. DOI: 10.1007/s10551-018-3794-5.

[14.] Byungchae, Jin (2019) The Practical Intelligence of Social Entrepreneurs: Managing the Hybridity of Social Enterprises. Published Online: 2019-04-24. DOI: https://doi.org/10.1515/erj-2018-0007.

[15.] Canestrino, R., Cwiklicki, M., Magliocca, P., Pawelek, B. (2020). Understanding social entrepreneurship: A cultural perspective in business research. Journal of business research, 110, 132-143. DOI: 10.1016/j.jbusres.2020.01.006.

[16.] Chandra, Y. (2017) Social Entrepreneurship as Emancipatory Work. Journal of Business Venturing forthcoming. DOI: 10.1016/j.jbusvent.2017.08.004.

[17.] Chell, E., Nicolopoulou, K. \& Karatas-Ozkan, M. (2020). Social entrepreneurship and enterprise: International and innovation perspectives. Entrepreneurship and regional development, 22 (6), 485-493. DOI: 10.1080/08985626.2010.488396. 
[18.] Choi, E. Kim, E., Kim, I., Choi, I. (2020). Attitude Toward Social Enterprises: A Comparison between For-Profit and Social Enterprise Employees. Sustainability. 12 (7). DOI: 10.3390/su12072720.

[19.] Choi, N. \& Majumdar, S. (2014). Social entrepreneurship as an essentially contested concept: Opening a new avenue for systematic future research. Journal of business venturing, 29 (3), 363 376. DOI: 10.1016/j.jbusvent.2013.05.001.

[20.] Cohen, H., Kaspi-Baruch, O., Katz, H. (2019). The social entrepreneur puzzle: the background, personality and motivation of Israeli social entrepreneurs. Journal of social entrepreneurship, 10 (2), 211-231. DOI: 10.1080/19420676.2018.1541010.

[21.] Corner, P.D., Kearins, K. (2018) Scaling-up social enterprises. The effects of geographic context. Journal of Management and Organization. 1-19.

[22.] Dacin T., Dacin M., Tracey P. (2011) Social entrepreneurship: A critique and future directions. Organization Science. 22 (5). 1203-1213.

[23.] Dacin, M.T., Dacin, P.A. Tracey, P. (2011). Social Entrepreneurship: A Critique and Future Directions. Organization science, 22 (5), 1203-1213. DOI: 10.1287/orsc.1100.0620.

[24.] Dacin, P.A., Dacin, M.T., Matear, M. (2010). Social Entrepreneurship: Why We Don't Need a New Theory and How We Move Forward From Here. Academy of management perspectives, 24 (3), 37 57. DOI: 10.5465/AMP.2010.52842950.

[25.] Dahiya, V.S. (2019) Social entrepreneurship as an antidote to state and market failure. Economic and Political Weekly. 54(51).

[26.] Datta, P.B. \& Gailey, R. (2012). Empowering Women Through Social Entrepreneurship: Case Study of a Women's Cooperative in India. Entrepreneurship theory and practice, 36 (3), 569-587. DOI: 10.1111/j.1540-6520.2012.00505.x.

[27.] Doherty, B., Haugh, H. \& Lyon, F. (2014). Social Enterprises as Hybrid Organizations: A Review and Research Agenda. International journal of management reviews, 16 (4), 417-436. DOI: 10.1111/ijmr.12028.

[28.] Drayton Bill. Social entrepreneurs don't want to help. They want to change the world. THE FOCUS. vol. XII/2. 53-57. URL: https://www.egonzehnder.com/cdn/serve/articlepdf/1513691150-c700cbda2b13bb4b6440f602b8d23ef1.pdf.

[29.] Ebrahim, A., Battilana, J. \& Mair, J. (2014). The governance of social enterprises: Mission drift and accountability challenges in hybrid organizations. Research in organizational behavior: an annual series of analytical essay and critical reviews, 34, 81-100. DOI: 10.1016/j.riob.2014.09.001.

[30.] Ekonomski pregled. 69 (5). 594-609.

[31.] Farinha, L., Sebastião, J. R., Sampaio, C., Lopes, J. (2020). Social innovation and social entrepreneurship: discovering origins, exploring current and future trends. International Review on Public and Nonprofit Marketing, 17 (1), 77-96.

[32.] Ferdousi, F. \& Mahmud P. (2019) Role of social business in women entrepreneurship development in Bangladesh: perspectives from Nobin Udyokta projects of Grameen Telecom Trust. Journal of global entrepreneurship research, 9 (1). DOI: 10.1186/s40497-019-0184-0.

[33.] Fernandez-Laviada, A., Lopez-Gutierrez, C., San-Martin, P. (2020). The Moderating Effect of Countries' Development on the Characterization of the Social Entrepreneur: An Empirical Analysis with GEM Data. Voluntas, 31 (3), 563-580. DOI: 10.1007/s11266- 020-00216-7.

[34.] Gandhi, T., Raina, R. (2018). Social entrepreneurship: the need, relevance, facets and constraints. Journal of global entrepreneurship research, 8 (1). DOI: 10.1186/s40497- 018-0094-6.

[35.] Grimes, M., Vogus, T. J., McMullen, J.S. and Miller T.L. (2013) Studying the Origins of Social Entrepreneurship: Compassion and the Role of Embedded Agency. The Academy of Management Review. 38(3): 2013. 460-463. DOI: 10.5465/amr.2012.0429.

[36.] Guo, L.X., Liu, C.F., Yain, Y.S. (2020). Social Entrepreneur's Psychological Capital, Political Skills, Social Networks and New Venture Performance. Frontiers in psychology, 11. DOI: 10.3389/fpsyg.2020.00925. 
[37.] Gupta, P., Chauhan, S., Paul, J., Jaiswal, M.P. (2020). Social entrepreneurship research: A review and future research agenda. Journal of business research, 113, 209-229. DOI: 10.1016/j.jbusres.2020.03.032.

[38.] Hojnik, B.B., Crnogaj, K. (2020). Social Impact, Innovations, and Market Activity of Social Enterprises: Comparison of European Countries. Sustainability, 12 (5). DOI: 10.3390/su12051915.

[39.] Jeong, S., Bailey, J.M., Lee, J., McLean, G.N. (2020). It's not about me, it's about us: a narrative inquiry on living life as a social entrepreneur. Social enterprise journal. DOI: 10.1108/SEJ-052019-0030.

[40.] Jill Kickul, Thomas S. Lyons. Understanding Social Entrepreneurship: The Relentless Pursuit of Mission in an Ever Changing World. United Kingdom: Routledge, 2016, 350 p.

[41.] Keohane, Georgia Levenson (2013), Social Entrepreneurship for the 21st Century: Innovation Across the Nonprofit, Private, and Public Sectors, New York: mc Graw Hill, 263 p.

[42.] Kerlin, J.A. (2010). A Comparative Analysis of the Global Emergence of Social Enterprise. Voluntas, 21 (2), 162-179. DOI: 10.1007/s11266-010-9126-8.

[43.] Kochlami, H., Davidsson, P. Obschonka, M., Yazdanfar, D., Lundstrom, A. (2020). The regional employment effects of new social firm entry. Small business economics. DOI: 10.1007/s11187020-00345-9.

[44.] Kolakovic, M., Turuk, M., Turcic, I. (2018). Social Entrepreneurship: Strategic Development in Croatia. Zagreb international review of economics \& business, 21 (2), 129-143. DOI: 10.2478/zireb-2018-0018.

[45.] Krocil, O., Pospisil, R. (2015). Comprehensive measurement of social enterprise impact.

[46.] Lambooy, T., Anthoni, P., Argyrou, A. (2020). Aren't we all pursuing societal goals in our businesses? Defining "societal purpose" as pursued by social enterprises. Sustainable development, 28 (3), 485-494 . DOI: 10.1002/sd.2039.

[47.] Liptrap, J.S. (2020). The social enterprise company in Europe: policy and theory. Journal of corporate law studies. DOI: 10.1080/14735970.2020.1744409.

[48.] Maalaoui, A., Le Loarne-Lemaire, S. \& Razgallah, M. (2020). Does knowledge management explain the poor growth of social enterprises? Key insights from a systematic literature review on knowledge management and social entrepreneurship. Journal of knowledge management. DOI: 10.1108/JKM-11-2019-0603.

[49.] Maseno, M., Wanyoike, C. (2020). Social Entrepreneurship as Mechanisms for Social Transformation and Social Impact in East Africa. An Exploratory Case Study Perspective. Journal of social entrepreneurship. DOI: 10.1080/19420676.2020.1755348.

[50.] Melkas, H. (2020). Social Enterprise: A Study of Its Prevalence, Role and Characteristics in Swedish-Speaking Regions of Finland. Tijdschrift voor economische en sociake geografie, 111 (2), 101-116. DOI: 10.1111/tesg.12366.

[51.] Moizer, J., Tracey, P. (2010). Strategy Making in Social Enterprise: The Role of Resource Allocation and Its Effects on Organizational Sustainability. Systems research and behavioral science, 27 (3), 252-266. DOI: 10.1002/sres.1006.

[52.] Monica, N., Tricia, B., Bent-Goodley and Gokul Mandayam (2019) Social Entrepreneurship, Intrapreneurship, and Social Value Creation: Relevance for Contemporary Social Work Practice. Washington : NASW Press. 299 p.

[53.] Newman, A., Neesham, C., Manville, G., Tse, Herman H. M. (2018). Examining the influence of servant and entrepreneurial leadership on the work outcomes of employees in social enterprises. International journal of human resources management, 29 (20), 2905-2926 DOI: 10.1080/09585192.2017.1359792.

[54.] Pereverzieva, A. \& Volkov V. (2020). Assessment and forecasting of favourable conditions for entrepreneurship development. Baltic Journal of Economic Studies, Vol. 6, No.3, Pp. 59-66. DOI: https://doi.org/10.30525/2256-0742/2020-6-3-59-66.

[55.] Pereverzieva, A. \& Volkov V. (2020). Assessment method of social enterpreneurships nature and its development. Management and entrepreneurship: trends of development, 1 (11), 113-131. DOI 10.26661/2522-1566/2020-1/11-08. 
[56.] Rosca, E., Agarwal, N. \& Brem, A. (2020). Women entrepreneurs as agents of change: A comparative analysis of social entrepreneurship processes in emerging markets. Technological forecasting and social change. DOI: 10.1016/j.techfore.2020.120067.

[57.] Roslan H., Hamid M., Ijab T. \& Bukhari S. (2019). Social entrepreneurship learning model in higher education using social network analysis. International Conference Computer Science and Engineering. Journal of Physics: Conference Series. 26-27 April 2019, Padang, Indonesia, 1339 (1). DOI: https://doi.org/10.1088/1742- 6596/1339/1/012029.

[58.] Sahasranamam S., Nandakumar M. K. Individual capital and social entrepreneurship: Role of formal institutions. Journal of Business Research. 2020. Vol. 107. Pp. 104-117. DOI: https://doi.org/10.1016/j.jbusres.2018.09.005.

[59.] Sengupta, S., Sahay, A., Croce, F. (2018). Conceptualizing social entrepreneurship in the context of emerging economies: an integrative review of past research from BRIICS. International entrepreneurship and management journal, 14 (4), 771-803. DOI: 10.1007/s11365-017-0483-2.

[60.] William A. Schambra (2010), "The Real Social Entrepreneurs" William E. Simon Lecture, the Manhattan Institute for Policy Research, New York City, 9 December 2010. URL: https://www8.gsb.columbia.edu/

[61.] Zulkefly N. A., Ghani N. A., Alquliti W. (2019). Identification of variables in predicting trends in social entrepreneurship. International Conference Computer Science and Engineering. Journal of Physics: Conference Series. 26-27 April 2019. Padang, Indonesia. Vol. 1339 (1). DOI: https://doi.org/10.1088/1742-6596/1339/1/012025.

\section{Biographical notes}

Anna Pereverzieva - Doctor of Economics, associate professor of International economics, natural resources and economic theory department, Zaporizhzhia National University. Since 2007, she has been working on scientific topics dedicated to human resources and the improvement of management methods within united territorial communities. Her scientific interests include the knowledge economy, human capital, human resources, and the development of united territorial communities. She has authored more than 70 scientific works, including 50 in scientific professional journals.

Volodymyr Volkov - Doctor of Technics, professor of Entrepreneurship, Management of Organizations and Logistics department, Zaporizhzhia national university. Scientific interests

- Management of real estate of territorial socio-economic entities in the conditions of decentralization. Has more than 160 scientific works, in particular, 12 inventions, 4 manuals with neck MES, 5 monographs, 1 textbook, and 4 copyright certificates on a scientific work. 